\title{
Impact of COVID-19 on the economy of micro, small and medium enterprises in Mexico
}

\section{Impacto del COVID-19 en la economía de las micro, pequeñas y medianas empresas de México}

SERRANO-TORRES, Ma. Guadalupe†*, ZAMBRANO-BALDIVIEZO, Oscar Javier, QUEZADAFLORES Ma. de la Luz and MÁRQUEZ-DE ANDA Camilo

Universidad Tecnológica de León, Guanajuato

Corporación Universitaria Minuto de DIOS- UNIMINUTO, Santander Colombia.

ID $1^{\text {st }}$ Author: Ma. Guadalupe, Serrano-Torres / ORC ID: 0000-0003-2229-6925, CVU CONACYT ID: 679788

ID $1^{\text {st }}$ Coauthor: Oscar Javier, Zambrano-Valdivieso / ORC ID: 0000-0003-0064-1062

ID $2^{\text {nd }}$ Coauthor: Ma. de la Luz, Quezada-Flores / ORC ID: 0000-0002-4726-2695, CVU CONACYT ID: 801109

ID $3^{\text {rd }}$ Coauthor: Camilo, Márquez-De Anda / ORC ID: 0000-0002-6800-0811

DOI: 10.35429/JMME.2020.7.4.1.6

Received July 27, 2020; Accepted December 14, 2020

\section{Abstract}

The objective of this research is to analyze the effects of COVID-19 on the economy and finances of micro, small and medium enterprises (MIPYMES) in Mexico, as well as the economic and financial strategies to survive this perfect storm, where the characteristic The main thing about this type of business is that it survives and is used to these events due to the way in which they are generally created and because they have a peculiar characteristic that the vast majority are family businesses. A mixed methodology is used that starts from grounded theory, is contrasted with findings from other national and international research that show the importance of analyzing the economic and financial effects for MSMEs. For the quantitative analysis, statistics of the companies that closed since the beginning of the pandemic were analyzed according to data collected by the INEGI Statistics Institute in 2020. As a result, it is obtained that the MIPYMES made use of their savings and previous returns, a change in the way of marketing their products, using online and home sales. This as economic and financial survival strategies in the red light months in each of the states of the Mexican Republic, and that affected all companies in the world.

Economic impact, Micro, small and Medium enterprises

\begin{abstract}
Resumen
La presente investigación tiene por objetivo analizar los efectos del COVID-19 en la economía y finanzas de las empresas micro, pequeñas y medianas empresas (MIPYMES) de México, así como las estrategias económicas y financieras para sobrevivir ante esta tormenta perfecta, donde la característica principal de este tipo de empresas es que sobreviven y están acostumbradas a estos acontecimientos por la manera como generalmente son creadas y por tener una peculiar característica que son la gran mayoría empresas familiares. Se utiliza una metodología mixta que parte de la teoría fundamentada, se contrasta con hallazgos de otras investigaciones nacionales e internacionales que evidencian la importancia de analizar los efectos económicos y financieros para las MIPYMES. Para el análisis cuantitativo se analizaron estadísticas de las empresas que cerraron desde el inicio de la pandemia según datos recabados por el Instituto de Estadística INEGI al año 2020. Como resultado se obtiene que las MIPYMES hicieron uso de sus ahorros y rendimientos anteriores, cambio en la forma de comercializar sus productos, utilizando ventas por internet y a domicilio. Esto como estrategias económicas y financieras de sobrevivencia en los meses de semáforo rojo en cada uno de los estados de la república Mexicana, y que afecto a todas las empresas del mundo.
\end{abstract}

Impacto económico, Micro, Pequeñas y Medianas empresas

Citation: SERRANO-TORRES, Ma. Guadalupe, ZAMBRANO-BALDIVIEZO, Oscar Javier, QUEZADA-FLORES Ma. de la Luz and MÁRQUEZ-DE ANDA Camilo. Impact of COVID-19 on the economy of micro, small and medium enterprises in Mexico. RINOE Journal-Macroeconomics and monetary economy. 2020. 4-7: 1-6

\footnotetext{
* Correspondence to Author (e-mail: gserrano@utleon.edu.mx)

$\dagger$ Researcher contributing first author.
} 


\section{Introduction}

Currently, a COVID-19 pandemic is being experienced that affects companies around the world in a health and economic way, putting their operation at risk. When the global isolation took place and in Mexico in the month of March, many people were fired from their jobs, virtual jobs and classes were carried out, leading companies to close temporarily and as progress was made and from the way of measuring the difficulty Of this pandemic, which were the traffic lights, only companies of first necessity were allowed to remain open to the general public. Hence the importance of analyzing the impact on the economy and finances of Mexican MSMEs and the strategies used by the companies that survived the first red light and the closure of non-essential companies.

\subsection{Justification}

Thus, the present research is charged with making known the economic and financial strategies used by the MIPYMES of Mexico to use as tools and survive in the face of this critical situation for the companies in question. This article presents the economic and financial strategies of micro and small companies and what they used during this pandemic. Their high business representation in Mexico with more than 95\%, accustomed to high tides and economic turbulence and to survive due to their own characteristics that distinguish them from being mostly family businesses, where their main objective is a family and private purpose and that They use as a strategy the reinvestment of profits without withdrawing and thus grow their business in an incalculable way, there is the counterpart that statistics show us that only one in three companies survives for more than three years.

\subsection{Problem}

The current economic crisis derived from this pandemic has caused companies that want to stay alive to choose to have financial and economic strategies that allow them to survive during this global crisis.

\subsection{General research question}

How many companies were economically and financially affected by the covid-19 pandemic in Mexico.

\subsection{Hypothesis}

Micro and small businesses in Mexico do not have the necessary competitiveness strategies to survive during this COVID -2019 pandemic.

\subsection{General purpose}

Analyze the economic and financial impact of MSMEs in Mexico.

\section{Theoretical framework 2.1 Current situation}

To get into the topic of MSMEs, we begin by understanding how business representation is in Mexico, According to the timely results of the 2019 economic censuses of the INEGI in our country, the following data is available. INEGI (2020).

In Mexico there are 4,773,995 companies, of which $95 \%$ are micro companies, $4 \%$ small companies, .80\% medium companies, $0.02 \%$ large companies, so $99.80 \%$ are our companies based on this research. The following graph shows the business representation to the year 2020 .

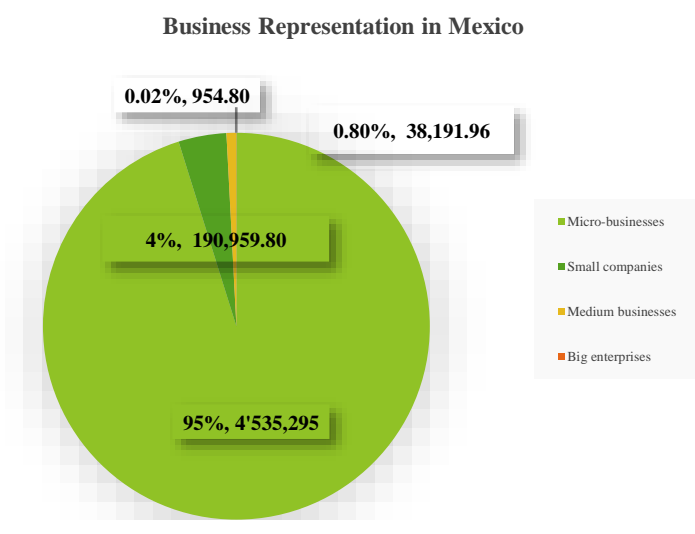

Figure 1 Business representation in Mexico, with data from INEGI, 2020

Own Elaboration

With data from the same INEGI, the generation of jobs of this type of companies is shown. In these 4,773,995 companies, 26'561,457 people worked: $37.8 \%$ worked in micro-businesses, $14.7 \%$ in small businesses, $15.9 \%$ in medium-sized companies and $31.6 \%$ in large economic units. The data is shown below in the following graphic. 


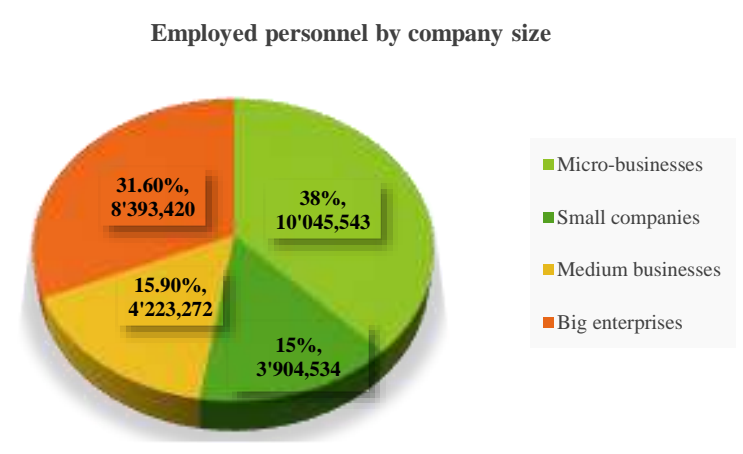

Figure 2 Employed personnel by company size. With data from INEGI

Own Elaboration

Now, to continue with our analysis of MSMEs, the contribution in income of this type of business is shown as the business backbone in our country. Because they represent $52 \%$ of the total income of the country's companies and large companies contribute $48 \%$ of the income, as shown in the following graphic.

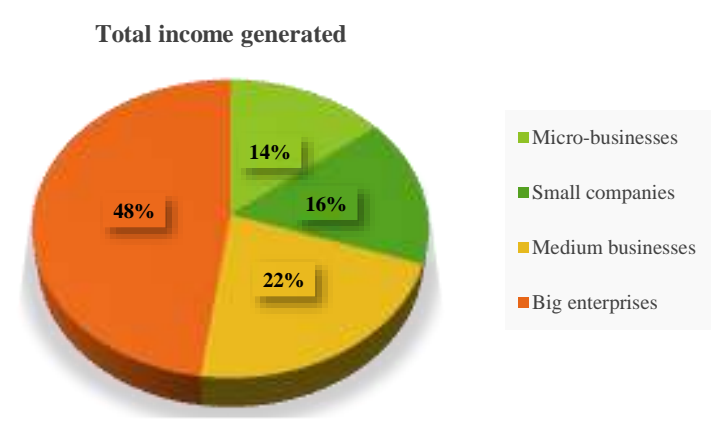

Figure 3 Income generation by company size. With data from INEGI

Own Elaboration

The following table shows the criteria that INEGI considers for the classification of companies by size, specifying that this classification is made based on the number of workers within the company.

\begin{tabular}{|l|l|}
\hline \multicolumn{1}{|c|}{ Company size } & Number of employed workers \\
\hline Micro enterprises & 0 to 10 busy people \\
\hline Small companies & $11-50$ busy people \\
\hline Medium businesses & $51-250$ busy people \\
\hline Big enterprises & From 250 - onwards \\
\hline
\end{tabular}

Table 1 Classification of companies by number of employed personnel. With data from INEGI, of own elaboration

\subsection{Economic impact}

In research carried out by Maravato (2020), by June of this year $77 \%$ would have financial problems or at least opened their doors temporarily closed due to the red traffic light in each of the states, this assumption was carried out in many establishments and the numbers The exact details of the definitive business closures are not exactly known due to the fact that there are businesses that are taxed informally and there are no records of them.

\subsection{COVID-19 measurement}

The World Health Organization, WHO (2020), updates daily the impact of the COVID-19 disease, this to take the necessary measures to face the pandemic, it is here where decisions are made according to the number of infections and deaths from This disease has a direct impact on companies, whether to continue operating or temporarily close their doors, to reduce the risk of contagion and reduce the spread of the disease.

\subsection{Birth of COVID-19 and its economic impact}

For Proum (2020), Mexican SMEs are in great economic distress, this putting as a precedent that the virus was born in the province of Wuhan, China and without losing sight of the bilateral relationship that exists between both countries, because that country It is the second country in imports and the fourth in exports, during 2019, China and Mexico made trade agreements, which resulted in an economic spill of more than 7 billion dollars economic risk, due to this antecedent it is not difficult to anticipate that it will exist an economic impact on our country and that directly affects our companies under study. For Blancas (2020), a very important problem during this pandemic is the main characteristic of MSMEs, most of the micro companies pay taxes in informal trade and this affects the economy of the country, being affected by the closure, for this the federal government implemented support and loan plans. JJ. As of December 31, Mexico closed the year with 125,807 deaths and 1 million 426,094 cases, this is discouraging for companies that are in danger of closing at least temporarily according to the traffic lights of each of the states of the Mexican Republic. 


\section{Methodology to be developed}

This research uses a mixed methodology, first of all based on grounded theory, it is contrasted with findings from other investigations with a systematic review of the literature to form the theoretical framework that responds to the objective of this research, supported by the question of research, Why analyze the Impact of COVID-19 on the economy of micro, small and medium-sized companies in Mexico. For the qualitative analysis, we start from statistical data from the 2019 economic census, results provided as of June 2020.

\section{Results}

Answering the research question why analyze the Impact of COVID-19 on the economy of micro, small and medium-sized companies in Mexico.

\subsection{The other tragedy as a consequence of COVID-19, closure of MSMEs}

For Téllez (2020), According to the study on Business Demography (EDN) 2020 published by the National Institute of Statistics and Geography (Inegi), the other tragedy is the closing to December of the current year of 1 000,000 one million MSMEs, this represents $20 \%$ of the companies that existed in 2019, this is a true tragedy because it is the backbone of the economy in Mexico and because of the number of jobs they generate and their contribution to the domestic product stupid.

This consequence has its impacts on the loss of almost four million jobs of almost $20 \%$, this due to the businesses that finally closed and due to the decrease in jobs of those that survived but had a decrease in their sales and production. In the same way, the third impact was on the generation of income of $21 \%$, the COVID-19 pandemic definitely has an impact on the economy of MSMEs in Mexico. This will result in thinking about a rapid recovery from the economic crisis, it is presumed that until the year 2022 due to the loss of companies, jobs and decreased income.
Companies that close in a covid-19 pandemic

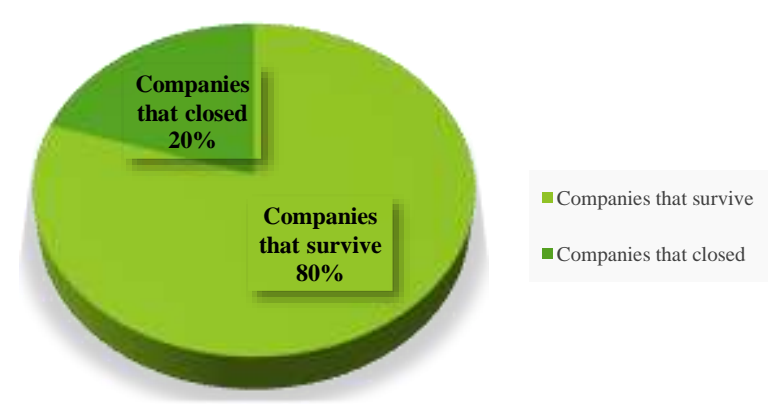

Figure 4 Companies that close during the covid-19 pandemic. With data from INEGI, of own elaboration

\subsection{Survival strategies for MSMEs against COVID-19}

For Cardona (2020), one of the survival strategies in the face of the most complex economic scenarios the world has ever experienced is the use of technology. It is expected that one out of every five companies will close their doors permanently during the following pandemic months and many others will decrease their income considerably, so companies must change their way of manufacturing and marketing their products to face the pandemic health and economic health in recent years.

Electronic commerce is expected to have an increase of at least $60 \%$, this pandemic came to accelerate the way of selling and buying products and services within the health and economic ills in terms of technology accelerated us and revolutionized a $1000 \%$ making us use technological tools to their maximum capacity if we want to survive and be on the list of companies that survive this COVID-19 pandemic. Let's just hope that these types of companies see digitization as an investment and not as an unnecessary expense is the taboo that each company has to go through to have a survival strategy.

\subsection{Tips for MSMEs in time of the COVID-19 pandemic}

For Castro (2020), one of the main tips is to investigate what our competitors are doing to survive and follow in their footsteps.

Another important tip is to act responsibly and respect the guidelines of operating responsibly to take care of our employees and customers.

SERRANO-TORRES, Ma. Guadalupe, ZAMBRANO-BALDIVIEZO, Oscar Javier, QUEZADA-FLORES Ma. de la Luz and MÁRQUEZ-DE ANDA Camilo. Impact of COVID-19 on the economy of micro, small and medium enterprises in Mexico. RINOE Journal-Macroeconomics and monetary economy. 2020 
Likewise, be resistant to change and lead our company or business to change and digitization with responsibility and tranquility.

On the other hand, maintain contact with our clients digitally through social networks and other internet media.

In the same way, use the digital resources available by our company.

The use of innovation in the production and marketing of products and services is an excellent strategy for the survival of companies in general.

Likewise, increased productivity and competitiveness are a survival tool that can make the difference between disappearing and remaining, despite the economic contingency.

And finally, adopt market research techniques, by staying close to our clients through social networks and also to our suppliers.

\section{Acknowledgments}

We thank the Technological University of León UTL for its support for this research to be published.

\section{Conclusions}

The MIPYMES under study economic structure of Mexico and of each of the countries worldwide due to their high representation, suffered in this pandemic a very delicate economic and financial situation by putting their survival at risk and being on the brink of closure definitively, They are tasked with digitizing their processes and way of marketing their products and making their purchases electronically.

The mortality statistics increased during the quarantine carried out by each of the states and which was occurring gradually as the traffic lights changed from green to red and put people's lives and health at risk, the statistics thus confirmed according to the economic census to the year 2019 where $20 \%$ of the companies closed permanently and $21 \%$ of the jobs were lost causing an unemployment problem that the federal government had to solve with support to companies, granting loans and support.
Revenues also decreased. It is concluded that the pandemic did have a direct relationship with the economic and financial impact of MSMEs. In addition, it is recommended as survival strategies the use of technology is recommended when digitizing the commercialization of products and services offered by companies as well as the way to supply their inputs.

It is concluded that innovation is an excellent survival strategy in the face of this pandemic and can make the difference between closing down or staying alive despite the economic turbulence.

Increasing the productivity of the company is another excellent strategy to improve the production of the products or services of the companies under study. To achieve survival and reduce the economic and financial impact within the company.

\section{References}

Blancas (2020), Expansión, "Cierre de COVID19 en México", recuperado en; https://politica.expansion.mx/mexico/2020/12/3 1/covid-19-mexico-cierra-el-ano-con-125-807muertes-y-1-millon-426-094casos?utm_source=push_notification

Cardona (2020), Forbes, "Tecnología: la clave para que las PyMEs sobrevivan a la nueva normalidad", recuperado en; https://www.forbes.com.mx/tecnologia-laclave-para-que-las-pymes-sobrevivan-a-lanueva-normalidad/

Castro (2020), Instituto Tecnologico de Monterrey, Campus Sonora, "Consejos para la supervivencia de las MIPYMES en pandemia COVID-19, recuperado en; https://tec.mx/es/noticias/sonoranorte/institucion/estrategias-y-consejos-parapymes-en-tiempos-de-pandemia

International Trade Centre, junio (2020), SME Competitiveness Outlook 2020: COVID-19: The Great Lockdown and its Impact on Small Business, junio (2020), , ISBN: 978-92-1103677-0, UN Sales Number: E.20.III.T.2, recuperado en: https://www.intracen.org/uploadedFiles/intrace norg/Content/Publications/ITCSMECO2020.pd $\mathrm{f}$

SERRANO-TORRES, Ma. Guadalupe, ZAMBRANO-BALDIVIEZO, Oscar Javier, QUEZADA-FLORES Ma. de la Luz and MÁRQUEZ-DE ANDA Camilo. Impact of COVID-19 on the economy of micro, small and medium enterprises in Mexico. RINOE Journal-Macroeconomics and monetary economy. 2020 
Maravato (2020), Expansión "El efecto covid19, en las PYMES, recuperado en: https://expansion.mx/opinion/2020/06/12/elefecto-covid-19-en-las-pymes

Proum, (2020), Forbes, "El estornudo del COVID-19 en las MIPYMES, Mexicanas", recuperado de: https://www.forbes.com.mx/elestornudo-del-covid-19-en-las-pymes-

mexicanas/

Organización Mundial de la Salud OMS, (2020), "El brote de la enfermedad COVID-19", recuperado de: https://www.who.int/es/emergencies/diseases/n ovel-coronavirus-

2019? gclid=EAIaIQobChMIs77n0M357QIVS ODACh3tFQiLEAAYASAAEgJkZPD_BwE

Téllez (2020), "La otra tragedia por pandemia cierran un millón de mipymes", recuperado en; https://www.elfinanciero.com.mx/empresas/ma s-de-un-millon-de-pymes-bajaron-las-cortinasde-manera-definitiva-por-el-covid-inegi 